\title{
Does the tumescent infiltration have an adverse effect on the full abdominoplasty flap?
}

Tümesent infiltrasyon tam abdominoplasti flebinde yan etkiye sahip olabilir mi?

\author{
Nazım Gümüş*, Sarper Yılmaz
}

Plastic, Reconstructive and Aesthetic Surgery Department (Assist. Prof. N. Gümüş, MD, Prof. S. Y1lmaz, MD), Cumhuriyet University School of Medicine, TR-58140 Sivas

\begin{abstract}
Aim. Abdominoplasty is one of the most common aesthetic surgical procedures, which restores abdominal contour and shape in patients who have significant abdominal deformations involving musculofacial laxicity and sagged abdominal wall. Besides its benefits, procedure has some complications such as seroma, hematoma, fat necrosis, wound dehiscense, skin necrosis and flap necrosis. All of which seems to be related either directly or indirectly with the blood perfusion of the abdominal flap. Methods. Presented here, is a patient who underwent full abdominoplasty with tumescent infiltration under conscious sedation after which a severe complication, flap necrosis developed in zone 1, suggesting that it was related with the full abdominoplasty technique combined with adrenaline. Results. In the follow-up examinations, wound care, antibiotic treatment, and debridment of the necrotic tissues under local anesthesia were performed during 6 months. Finally wound closed itself, leaving significant lower abdominal scar which needed a major revisional surgery. Conclusion. In full abdominoplasty procedure, when combined with tumescent anesthesia adrenaline content of the tumescent may compromise blood perfusion of the zone 1, so preventive procedures such as limited lateral dissection of the flap, protection of the some musculocutaneous perforators and short transverse incision, should be kept in mind to avoid ischemia of the flap.
\end{abstract}

Keywords: Tumescent, abdominoplasty, ischemia, flap necrosis, complication

\section{Özet}

Amaç. Abdominoplasti, kas-fasya gevşekliği ve sarkmış karın duvarını içeren belirgin karın şekil bozukluğu olan hastalarda, karın şekil ve sınırlarını yeniden düzelten en sık estetik cerrahi işlemlerden biridir. Faydalarının yanısıra işlem hematom, yağ nekrozu, yara açılması, cilt nekrozu ve flep nekrozu gibi bazı komplikasyonlara sahiptir. Bunların hepsi doğrudan ya da dolaylı olarak abdominal flebin kan dolaşımı ile ilgili görünmektedir. Yöntem. Burada, bilinçli sedasyon altında tümesent infiltrasyon ile tam abdominoplasti geçiren, sonrasında ciddi bir komplikasyon olan zon 1' de flep nekrozu gelişen, bunun tam abdominoplasti tekniği ile birleştirilmiş adrenaline ile ilişkili olduğu düşünülen hasta sunuldu. Bulgular. Takip muayenelerinde yara bakımı, antibiyotik tedavisi ve nekrotik dokuların lokal anestezi altında debritmanı 6 ay süresince yapıldı. Sonuçta yara, ciddi revizyon cerrahisi gerektiren belirgin bir skar bırakarak kendiliğinden kapandı. Sonuç. Tam abdominoplasti işlemi, tümesent anestezi ile birleştirildiğinde, tumesentin adrenalin içeriği zon 1 de kan dolaşımını bozabilir, bu nedenle kısa transvers kesi, kas-deri perforatörlerin korunması ve sınırlı yan diseksiyon gibi koruyucu işlemler flep iskemisinin önlenmesi için akılda tutulmalıdır.

Anahtar sözcükler: Tumesent, abdominoplasti, iskemi, flep nekrozu, komplikasyon

Geliş tarihi/Received: August 16, 2011; Kabul tarihi/Accepted: November 07, 2012

*Corresponding author:

Dr. Nazım Gümüş, Plastik Rekonstrüktif ve Estetik Cerrahi Anabilim Dalı, Cumhuriyet Üniversitesi Tıp Fakültesi, TR-58140 Sivas. E-mail: gumus1970@hotmail.com 


\section{Introduction}

Abdominoplasty is one of the most common aesthetic surgical procedures, which completely restores abdominal contour and shape in patients who have significant abdominal deformations involving musculofacial laxicity and sagged abdominal wall with skin and fat tissue. In most patients, change of the abdominal apperance is related to the pregnancy. Besides its benefits, abdominoplasty procedure has some complications such as seroma, hematoma, fat necrosis, wound dehiscense and skin necrosis. Both small and large flap necrosis have been mentioned as a minor complication in the literature, resulting in long time follow-up, revisions, unacceptabl scars and sometimes severe problems between the relationship of the surgeon and patient [1-5]. Most of these complications seem to be related with the blood perfusion of the abdominal flap that is divided into 3 vascular territories supplied by the different arterial sources. Naturally, every event that has an adverse effect on flap perfusion such as hematoma, flap or suture tension, liposuction or thinning of the flap, wide undermining or any systemic disease involving the microcirculation or vascular structures, has an increased risk for compromizing of the flap viability and is capable of progressing with ischemia, flap necrosis or other wound related complications [6-9]. Tumescent infiltration technique mainly consists of injecting large volume of fluid containing adrenaline and an anesthetic agent such as lidocaine or bupivacaine, which produces swelling and firmness (tumescence) of the skin and subcutaneous areas, leading to severe vasoconstruction due to adrenaline within 10 to 30 minutes after the administration [10-13]. It provides both intraoperative and postoperative analgesia, reduced bleeding and an improved plane of dissection, resulting in easier and faster operation. Moreover, it also makes early recovery after the surgical intervention because of the reduced postoperative swelling and bruising. The technique can be used either under general anesthesia or in combination with intravenous sedation [10-13].

Presented here was a patient who underwent a full abdominoplasty procedure with tumescent infiltration resulting in a severe complication, flap necrosis which may be related to adrenaline.

\section{Case report}

A 34-year-old woman presented to our clinic with the complaints of severe abdominal deformation and changes after her deliveries. On the examination, there were skin and fat excess, sagged abdominal wall, musculofacial laxity and umbilical deformation, needing an abdominoplasty operation to restore the abdominal shape and contour entirely (Figure $1)$.

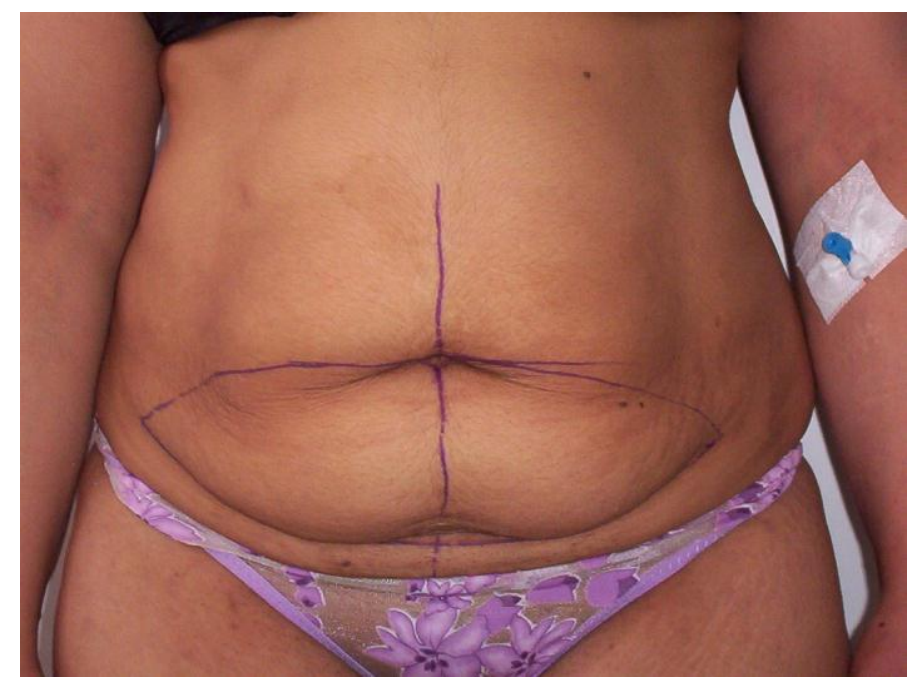

Figure 1. Preoperative view of the patient with abdominal deformation. 
Prior to the surgery, abdominal skin was marked in the standing position, and then under procedural sedation and analgesia for which fentanyl hydrochloride and midazolam were used by an anesthesiologist, surgery was started. Sedation and analgesia result in a depressed level of consciousness, allowing the patient to maintain airway control independently and continuously. Tumescent solution of ringer lactate was prepared in the operating room, which consisted of lidocaine in $0.05 \%$ of dilution with $1: 1,000,000$ of epinephrine. After warming, it was given into the subcutaneous fat layer of the abdomen by using a long fine neddle to avoid any possible injury to the tissues. All abdominal area extending from xyphoid and costal margins to the pubic and inguinal regions, was infiltrated with $1300 \mathrm{~mL}$ of tumescent solution. After waiting 15 minutes, an incision was made over suprapubic skin crease and then undermining of the abdominal flap was done meticulously on the rectus abdominus muscle, extending up to the xyphoid and costal margins, and lateral to the rectus muscles. After the flap was dissected completely, rectus fascia was plicated on the midline with sutures which were placed along the midline in both supra and infra umbilical areas, and then lower part of the flap including excess skin and fat was removed in the usual manner. Umbilical stalk was brought out through the skin incision which was a rombus shape. Although bleeding was very little, meticulous hemostasis was done with bipolar electrocautery, and two drains were placed under the abdominal flap. Skin incision was closed without any tension of the flap at the suture line. A compression garment was worn at the table after the surgery, and continued for 4 weeks. Allied procedures such as liposuction were not performed, and the undermined flap was not thinned.

\section{Results}

In the postoperative course, less pain and earyl recovery appeared, so she was encouraged to be as mobile as permitted by comfort, but strenuous activities and heavy lifting were restricted. After an overnight stay in the hospital the patient was discharged 48 hours after the intervention. She was again seen to change the dressing, and remove the drains when their outputs were less than $50 \mathrm{~mL}$ per day. However, ischemia of the abdominal flap lower the neoumbilicus at the midline appeared, resulting in severe necrosis of the flap (Figure 2, 3).

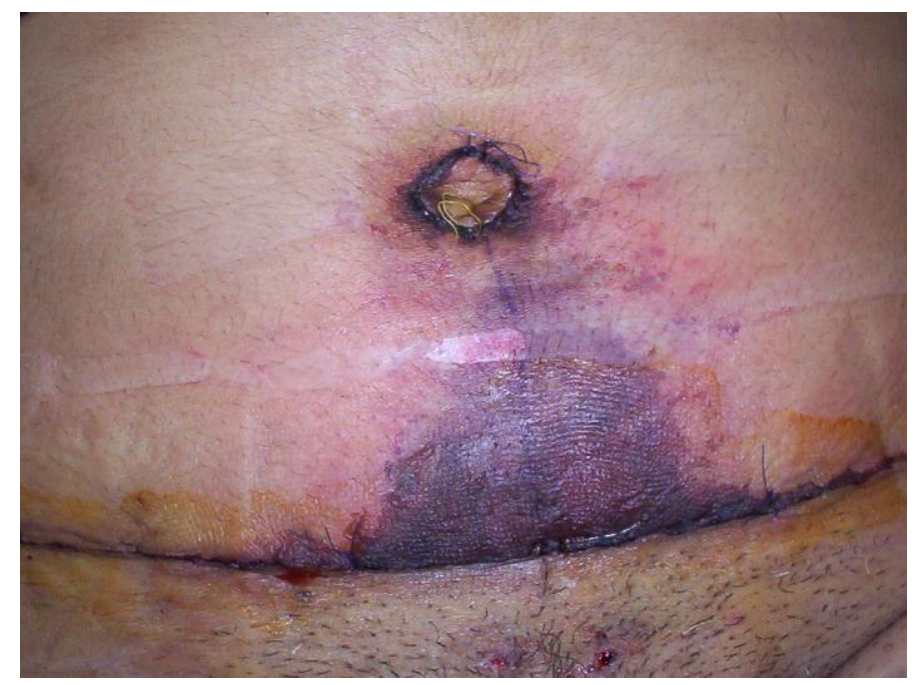

Figure 2. Two days later the operation, apperance of the ischemic findings of the abdominal flap below the neoumbilicus. Note that there was not any tension in the flap at the suture line. 


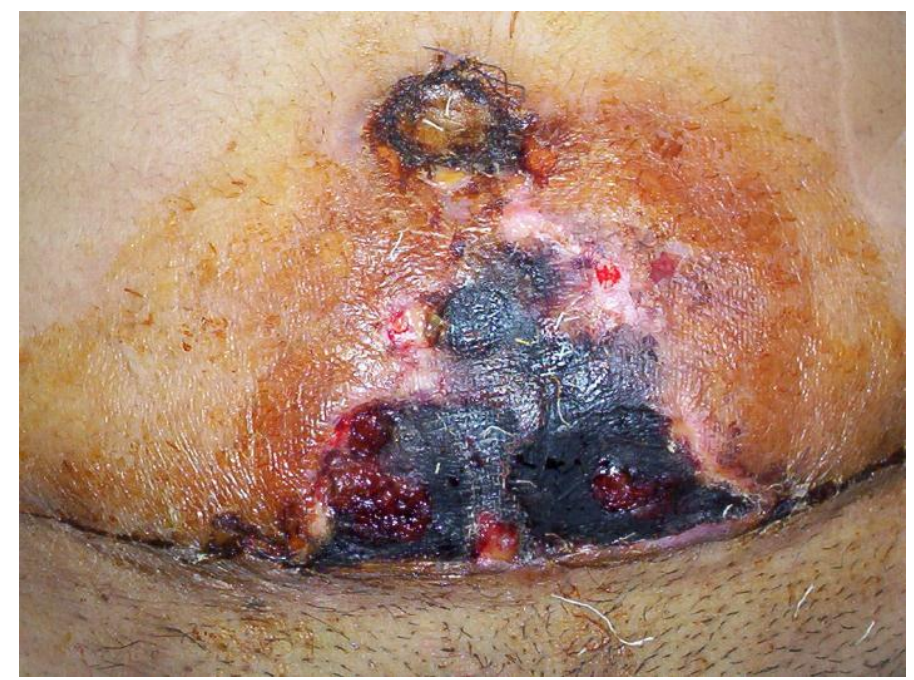

Figure 3. Abdominal flap necrosis involved both skin and fat tissue on the 20th day after surgery.

In the follow-up examinations, wound care, antibiotic treatment, and debridement of the necrotic tissues under local anesthesia were performed during 6 months. Finally wound closed itself, leaving significant lower abdominal scar which needed a major revisional surgery (Figure 4).

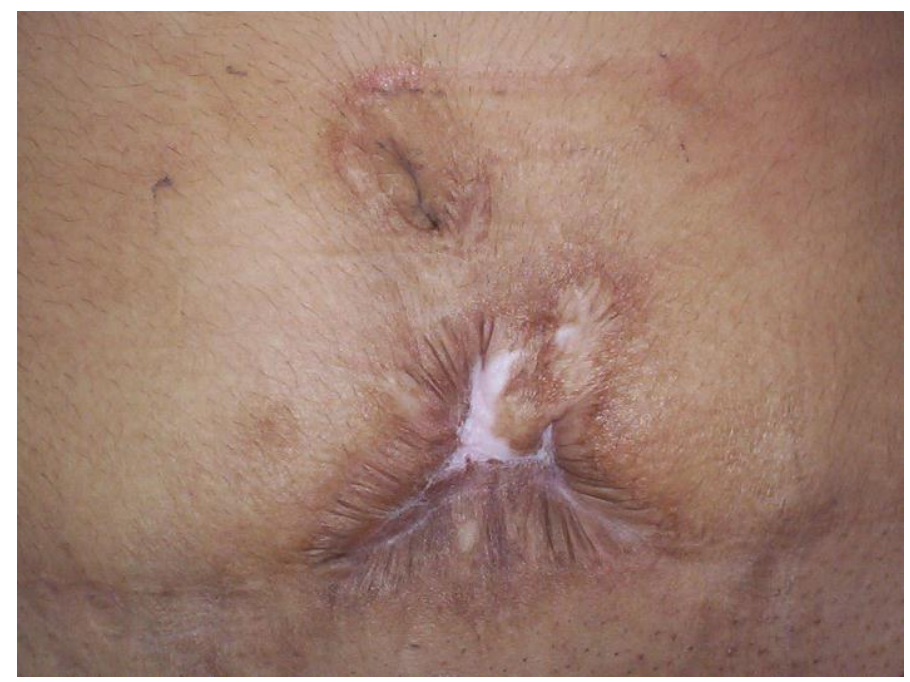

Figure 4. Apperance of the abdomen at about 1 year later the surgery.

\section{Discussion}

After the experience with flap necrosis of a standard cervicofacial rhytidectomy performed with tumescent local anesthesia and intravenous sedation, Ramirez firstly noted the possible adverse effect of the tumencent anesthesia on the blood perfusion of the undermined flaps. Although dissection of the entire flap resulted in a thick subcutaneous flap in which most of the fat overlying the platysma muscle was included, and some of the larger musculocutaneous perforators from the platysma going to the overlying skin were preserved, flap necrosis appeared. He claimed that at least three factors contributed to superficial loss of the facial flap, which were the time between injection and surgical incision and undermining; hydrostatic pressure in the skin that reveals a definitive peau d'orange appearance, and the vasoconstrictive effect of epinephrine [14]. However, LaTrenta opposed these opinions about servicofacial flap 
necrosis with his experience based on cervicofacial rhytidectomy with tumescent infiltration. He suggested that hydrodissection taken place by tumescent infiltration was the most important factor in developing of flap necrosis rather than the mentioned causes. In his opinion, if a surgeon is not extremely cautious, while giving tumescent injection, a substantial amount of misdirected dissection in dermal plane by the hydrodissection can be created and then when this plane joins with the dissection in the deep subcutaneous plane performed by the surgeon may result in flap necrosis [15]. As abdominoplasty is a very different surgical procedure from the cervicofacial rhytidectomy when corresponded with the flap dissection, thickness, composition, blood supply, and anatomical layes of the flap, necrosis of the abdominoplasty flap seems to be related to a large number of causes described clearly in the literature. Risk factors for the occurence of major or minor wound complications after abdominoplasty have been described in the various studies, including smoking, previous abdominal surgery, hypertension, and male sex [16]. Obesity is another well known risk factor for complications after abdominoplasty. A body mass index higher than $30 \mathrm{~kg} / \mathrm{m}^{2}$ at the time of surgery is a cause for wound complications. Suturation of the distal edge of the abdominal flap under significant tension may be considered to be a risk for potential wound problems [16-17].

Vasoconstrictive effect of the tumescent infiltration poses as a risk factor for the blood supply of the flap, especially in the zone 1 which may be considered as a tip region of the flap. Hydrostatic pressure in the skin and elapsed time between the injection and surgery are not possible causes of the flap necrosis, as the tumescent solution is given into the fat layer of the abdominal flap, not into the skin, and the time passed after the administration is about 15 minutes for which Ramirez recommends 15 to 30 minutes. As mentioned by LaTrenta, hydrodissection may lead to double-cut, both in dermal plane and in the deep subcutaneous plane, but it is impossible for the abdominal flap because of its anatomical and surgical differences from the cervicofacial rhytidectomy. In the abdominoplasty, tumescent solution is given into the subcutaneous layer and fat tissue by injecting deep from skin to the abdominal fascia. It is likely that adrenaline content of the tumescent solution acts as a vasoconstrictor agent in the abdominal flap, leading to significant decrease in the blood perfusion. Especially, in part of the flap below the neoumbilicus at the midline, blood flow reduces much more than in the other parts of the flap, being capable of developing ischemia. In full abdominoplasty technique, in this region of the flap blood perfusion frequently decreases, even if any agent altering the blood flow is not used, because of the loss of the larger musculocutaneous perforators of rectus muscles.

Mayr revealed the effect of abdominoplasty on abdominal wall perfusion with a quantitative evaluation, using the technique of dynamic laser fluorescence videoangiography. After suturing the abdominal flap in place, blood perfusion was measured in the region between the umbilicus and the transverse scar (zone 1). The increment of fluorescence was recorded and compared with the intensity curve of normal tissue that was not involved in surgery (thoracic wall) [6]. The results in all patients indicated a significant impairment of the vascular supply of zone 1 , showing that conventional abdominoplasty with extended undermining and division of the superficial and the deep arterial systems causes profound devascularization of the abdominal flap. These findings may help us to explain the flap necrosis in this patient who underwent full abdominoplasty with tumescent procedure. It is most likely that blood flow in the zone 1 must have decreased down to the critical level as a result of surgery and adrenaline, and then when compensatory blood supply became insufficient to supply the infraumbilical area, ischemia and necrosis inevitably taken place. Generally, local anesthetic agents combined with adrenaline are not used in the tip regions of the body such as finger, toe, ear lobule and penis to avoid danger of ischemia. Similarly, zone 1 of the abdominoplasty flap must be accepted as a tip region and during the surgery either adrenaline is not given into this area, or blood flow should be protected with surgical techniques such as limited lateral dissection of the flap over the rectus fascia, protection of musculocutaneous perforators and short transverse incision to support blood flow of the flap [7, 8, 10]. 
Tumescent anesthesia has widely been used to facilitate the abdominoplasty procedure, as it provides not only anesthesia, less bleeding and easy dissection during abdominoplasty, but also less pain, reduced swelling and bruising in postoperatively as well. However, in full abdominoplasty adrenaline content of the tumescent may compromise blood perfusion of the zone 1, so preventive procedures should be kept in mind to avoid ischemia of the flap.

\section{References}

1. Neaman KC, Hansen JE. Analysis of complications from abdominoplasty: a review of 206 cases at a university hospital. Ann Plast Surg 2007; 58: 292-8.

2. Stewart KJ, Stewart DA, Coghlan B, Harrison DH, Jones BM, Waterhouse N. Complications of 278 consecutive abdominoplasties. J Plast Reconstr Aesthet Surg 2006; 59: 1152-5.

3. Rogliani M, Silvi E, Labardi L, Maggiulli F, Cervelli V. Obese and nonobese patients: complications of abdominoplasty. Ann Plast Surg 2006; 57: 336-8.

4. Hensel JM, Lehman JA Jr, Tantri MP, Parker MG, Wagner DS, Topham NS. An outcomes analysis and satisfaction survey of 199 consecutive abdominoplasties. Ann Plast Surg 2001; 46: 357-63.

5. Vastine VL, Morgan RF, Williams GS, Gampper TJ, Drake DB, Knox LK, Lin KY. Wound complications of abdominoplasty in obese patients. Ann Plast Surg 1999; 42: 34-9.

6. Mayr M, Holm C, Höfter E, Becker A, Pfeiffer U, Mühlbauer W. Effects of aesthetic abdominoplasty on abdominal wall perfusion: a quantitative evaluation. Plast Reconstr Surg 2004; 114: 1586-94.

7. Graf R, de Araujo LR, Rippel R, Neto LG, Pace DT, Cruz GA. Lipoabdominoplasty: liposuction with reduced undermining and traditional abdominal skin flap resection. Aesthetic Plast Surg 2006; 30: 1-8.

8. Hafezi F, Nouhi A. Safe abdominoplasty with extensive liposuctioning. Ann Plast Surg 2006; 57: 149-53.

9. Shestak KC. Marriage abdominoplasty expands the mini-abdominoplasty concept. Plast Reconstr Surg 1999; 103: 1020-31.

10. Abramson DL. Tumescent abdominoplasty: an ambulatory office procedure. Aesthetic Plast Surg 1998; 22: 404-7.

11. Rosenberg MH, Palaia DA, Bonanno PC. Abdominoplasty with procedural sedation and analgesia. Ann Plast Surg 2001; 46: 485-7.

12. Kryger ZB, Fine NA, Mustoe TA. The outcome of abdominoplasty performed under conscious sedation: six-year experience in 153 consecutive cases. Plast Reconstr Surg 2004; 113: 1807-17.

13. Byun MY, Fine NA, Lee JY, Mustoe TA. The Clinical Outcome of Abdominoplasty Performed under Conscious Sedation: Increased use of fentanyl correlated with longer stay in outpatient unit. Plast Reconstr Surg 1999; 103: 1260-66.

14. Ramirez OM, Galdino G. Does tumescent infiltration have a deleterious effect on undermined skin flaps? Plast Reconstr Surg 1999; 104: 2269-72.

15. LaTrenta GS. Does tumescent infiltration have a deleterious effect on undermined skin flaps? Discussion. Plast Reconstr Surg 1999; 104: 2273-7.

16. Momeni A, Heier M, Bannasch H, Stark GB. Complications in abdominoplasty: a risk factor analysis. J Plast Reconstr Aesthet Surg 2009; 62: 1250-4.

17. Fenn CH, Butler PEM. Abdominoplasty wound-healing complications: Assisted closure using foam suction dressing. Br J Plast Surg 2001; 54: 348-51. 